Article received on March $4^{\text {th }} 2017$

Article accepted on March $10^{\text {th }} 2017$

UDC: 786.2 .087 .3

78.071.1 Савић M.

\title{
Ivana Medic*
}

Institute of Musicology, Serbian Academy of Sciences and Arts

\section{PARENTING THE PIANO: MIROSLAV MIŠA SAVIĆ'S ST. LAZARUS WALTZ}

\begin{abstract}
This article deals with a work by a contemporary Serbian composer Miroslav Miša Savić (b. 1954): St. Lazarus Waltz for one or two grand pianos, with or without children's toy pianos. Since St. Lazarus is a children's holiday, the composer's idea was to depict children by toy pianos, while the grand pianos are 'parents'. The waltz exists in several versions: from the first one, where the children pianos are quite small and their musical parts very restricted, to the version for two 'adult' pianos, which describes the moment in life when children have grown up and left their parental home. Aside from exploring these musical 'family ties', Savić implements a simple yet ingenious constructive principle in all versions of this waltz. The structure of the piece is based on the exploitation of the system of equal temperament and on the Fibonacci row, and this frame is filled with several layers of musical references, including: Johann Sebastian Bach and other composers who wrote 'well-tempered' piano music; repetitive/processual minimalism, a style that Savić and his peers brought into Serbian music, but have since evolved
\end{abstract}

* Author contact information: dr.ivana.medic@gmail.com 
in different directions; the Serbian tradition of romantic salon piano pieces; finally, the Orthodox tradition, but referenced in a way very different from the 'neo-Orthodox' trend that has been present in Serbian art music since the late 1980s.

Key words: Miroslav Miša Savić, St. Lazarus Waltz, parents and children, toy pianos, Serbian Orthodox Church, The Well-Tempered Clavier, Nada Kolundžija, LP Duo.

\section{Introduction}

Born in 1954, Serbian composer Miroslav Miša Savić studied composition with Vasilije Mokranjac at the Belgrade Faculty of Music. However, rather than following the strictures of academic (neo-)Classicism, which at that time was the preferred method of training young composers, Savić and his fellow students Vladimir Tošić (b. 1949), Miodrag Lazarov (b. 1949) and Milimir Drašković (1952-2014) ${ }^{1}$ soon parted ways with the establishment and formed an experimental group OPUS 4, devoted to multimedia artistic experiments in the spirit of minimalism and fluxus. ${ }^{2}$ After several decades of such experimentation, in recent years Savić has returned to the more conventional methods of artistic expression. He has written a series of piano works, among them St. Lazarus Waltz for one or two grand pianos, with or without children's toy pianos. A collection of his works for one or two pianos was published in $2016 .^{3}$

Since St. Lazarus is a children's holiday, the composer's idea was to depict children by toy pianos, while the grand pianos are 'parents'. The waltz exists in several versions, with slightly different titles and scored for different combinations of grand pianos and children's toy pianos; however, all versions are united by the same formal design and musical material. Moreover, all versions of the waltz feature multiple layers of musical referentiality, which situate it firmly in the realm of musical postmodernism. I will begin my analysis by overviewing the composer's constructive principle, which is easily adapted to different key-

1 Other composers, who were not official members of the OPUS 4 group, but rather their kindred spirits in the rebellion against the academic establishment, included Miloš Petrović (1952-2010; pianist, harpsichordist, composer and novelist) and Miloš Raičković (b. 1956, composer and conductor, who currently resides in New York City, USA).

2 Serbian musicologist Marija Masnikosa has written extensively on the activities of OPUS 4: cf. Marija Masnikosa, Muzički minimalism: američka paradigma i differentia specifica u ostvarenjima grupe beogradskih kompozitora [Musical Minimalism: American Paradigm and Differentia Specifica in the Works by a Group of Belgrade Composers], Belgrade, Clio, 1998; idem., "The Reception of Minimalist Composition Techniques in Serbian Music of the Late 20th Century", New Sound 40, 181-190; etc.

3 Miroslav Miša Savić, Animirani brojevi - Animated Numbers, Belgrade, Vertical Jazz, 2016. 
board instruments; then, I will discuss different versions of this piece, which bear the same or similar titles; afterwards, I will uncover the layers of musical references embedded in this piece and, finally, attempt to reveal its possible meaning(s).

\section{Spring Blossom}

The impetus for writing St. Lazarus Waltz came from the acclaimed Serbian pianist Nada Kolundžija, to whom the piece is dedicated; she needed new works for her piano recital 'Waltz in the 20th and 21st Centuries' that took place in October 2005, during the 37th edition of BEMUS Festival. As a frequent performer of Savić's works, Kolundžija asked him to compose a waltz - something that he had never done before, although he had actively written music since the mid1970s. Despite a very tight deadline, Savić took up the challenge and decided to write a waltz dedicated to St. Lazarus.

The celebration of Saint Lazarus, also known as Vrbica or Lazareva subota [Lazarus Saturday], is one of the most cheerful holidays in the calender of the Serbian Orthodox Church, because it is a children's holiday. It has its origins in the Eastern Christian feast of Lazarus Saturday. The feast celebrates the resurrection of Lazarus of Bethany and Christ's arrival in Jerusalem, where he was greeted by the children. It is celebrated on a Saturday before the holiday of $\mathrm{Cve}$ $t i$ - the sixth week of the Great Fast (Lent). Parents bring their children, even babies, to the church, dressed in nice clothes. Children wear small bells around their necks and flowers in their head. Children also take part in the procession around the church, and everybody sings the song for Lazarus Saturday.

Due to this holiday's association with children and spring blossoming, Savić worked out a simple yet ingenious constructive principle. The structure of the piece is based on the Fibonacci row: just like the leafy plants grow and add new leaves and branches in accordance with the proportions of the Fibonacci row, so the music of this piece grows and develops in a similar way. Simultaneously, another process takes place, one that is based on the 'well-tempered' tradition and sees the main theme go through the entire circle of fifths. In order to 'depersonalise' and thus 'universalise' his musical 'core' or 'seed', whilst also denying himself the prerogatives of the 'Creator', Savić did not compose the main theme himself, but downloaded a random MIDI file from Internet, and then subjected it to a set of pre-determined transformations. The composer has said:

The underlying idea behind the composition is the rhythmic throb of the form. It has been achieved by the lenghts of the fragments projected in advance to be mutually strictly proportional. The structure of the composition is formed by loops, which I made from ad hoc material in MIDI format downloaded from the Internet... by cop- 
ying and pasting it, I adjusted to the proportional relations between the fragments (with slight changes). Thus I accomplished several goals simultaneously: a complete piece of music in which not a single note has been composed by me, apart from the theme of St. Lazarus, which is repeated like a mantra in the toy piano; a dance in the spirit of the waltz without the input of the composer's ego; a revival of a classical piece of music using non-traditional means. The sonic effect has satisfied my expectations. ${ }^{4}$

By stating this, the composer actually underplays his contribution to the creation of this piece: namely, although he did not compose the main theme, he is the one who decided on the proportions of the piece and the type of transformations that should be carried out. In manipulating the material, he draws on the avantgarde heritage (serialism and processual minimalism), but also on the role of the producer of popular music, who selects and combines samples and loops, and thus creates a new song or a dance number.

The entire piece consists of 144 bars (12x12); each 12-bar section is in a different key. Following the 'well-tempered' model established by Johann Sebastian Bach in his tour-de-force Das Wohltemperierte Clavier vols. I (1722) and II (1744) - which takes the listener through the entire circle of fifths and which was only possible on new keyboard instruments with equal temperament - and later developed in different ways by composers as diverse as Frédéric Chopin (24 Preludes for piano Op. 28, 1839), Paul Hindemith (Ludus tonalis, 1942) or Dmitri Shostakovich (24 Preludes and Fugues, 1951), Savić moves the randomly chosen theme through a series of keys, i.e. modes. Although Savić does not explore all 24 major and minor keys, but only 12 modes, it is sufficient for him to encompass the entire chromatic total and close the circle of fifths in upward and downward motions. In the original 2005 version of the piece, the keys/modes unfold in the following sequence (Table 1):

Table 1: Sequence of keys/modes in St. Lazarus Waltz

\begin{tabular}{|l|l|l|}
\hline KEY / MODE & BARS & ACCIDENTALS \\
\hline \multicolumn{2}{|c|}{ The first stage - from E Phrygian to E\# Phrygian } \\
\hline E Phrygian & $1-12$ & no accidentals \\
\hline E Aeolian (= E Minor natural) & $13-24$ & 1 sharp (F\#) \\
\hline E Dorian & $25-36$ & 2 sharps (F\#, C\#) \\
\hline E Mixolydian & $37-48$ & 3 sharps (F\#, C\#, G\#) \\
\hline E Ionian (= E Major) & $49-60$ & 4 sharps (F\#, C\#, G\#, D\#) \\
\hline
\end{tabular}

4 The composer's commentary on the waltz in: Animated Numbers, Ibid., 123. 
Medić, I.: Parenting the Piano: Miroslav Miša Savić's St. Lazarus Waltz

\begin{tabular}{|l|l|l|}
\hline & $61-72$ & 5 sharps (F\#, C\#, G\#, D\#, A\#) \\
\hline E Lydian & $73-84$ & 6 sharps (F\#, C\#, G\#, D\#, A\#, E\#) \\
\hline E\# Locrian & $85-96$ & 7 sharps (F\#, C\#, G\#, D\#, A\#, E\#, B\#) \\
\hline E\# Phrygian & \multicolumn{2}{|c|}{ The second stage - from F Phrygian to F Major } \\
\hline $\begin{array}{l}\text { Enharmonic equivalent: } \\
\text { E\# Phrygian = F Phrygian }\end{array}$ & 5 flats (Bb, Eb, Ab, Db, Gb) \\
\hline F Aeolian (= F Minor Natural) & $97-108$ & 4 flats (Bb, Eb, Ab, Db) \\
\hline F Dorian & $109-120$ & 3 flats (Bb, Eb, Ab) \\
\hline F Mixolydian & $121-132$ & 2 flats (Bb, Eb) \\
\hline F Ionian (= F Major) & $133-144$ & 1 flat (Bb) \\
\hline
\end{tabular}

The second process that takes place simultaneously with the tonal transpositions, but does not exactly match it, is the development of the musical material on the basis of the Fibonacci sequence of numbers, in which every number after the first two is the sum of the preceding two: $1,1,2,3,5,8,13,21,34,55$ etc. This sequence of numbers has been used as a form-building principle by many composers, including Claude Debussy, Béla Bartók, Igor Stravinsky, Sofia Gubaidulina et al.

The structure of Savić's St. Lazarus Waltz follows the proportions of the Fibonacci sequence almost exactly, with just one 'extra' bar interpolated between numbers 34 and 55 in the sequence, in order to adjust the sum of 143 to the total of $144(12 \times 12)$ bars (Table 2$)$ :

Table 2: Structural disposition of St. Lazarus Waltz

\begin{tabular}{|l|l|l|}
\hline PRINCIPLE & NUMBER OF BARS & $\begin{array}{l}\text { TOTAL } \\
\text { SUM }\end{array}$ \\
\hline Circle of fifths & $12+12+12+12+12+12+12+12+12+12+12+12$ & 144 \\
\hline Fibonacci sequence & $1+1+2+3+5+8+13+21+34(+1)+55$ & 144 \\
\hline
\end{tabular}

In Table 3 below we may observe the structural design of the piece according to the Fibonacci sequence, while the column on the right provides the comparison to the $12 \times 12$ tonal transpositions based on the circle of fifths. It is quite obvious that they do not match: this mismatch actually prevents the piece from becoming schematic and secures a balance between tonal symmetry and structural assymetry: 
Table 3: Form and structure of St. Lazarus Waltz based on the Fibonacci sequence

\begin{tabular}{|c|c|c|}
\hline $\begin{array}{l}\text { FIBONACCI } \\
\text { SEQUENCE }\end{array}$ & $\begin{array}{l}\text { BAR NUM- } \\
\text { BER(S) }\end{array}$ & $\begin{array}{l}\text { TONAL } \\
\text { CHANGES }\end{array}$ \\
\hline 1 & 1 & \multirow[t]{5}{*}{ E Phrygian } \\
\hline 1 & 2 & \\
\hline 2 & $3-4$ & \\
\hline 3 & $5-7$ & \\
\hline 5 & 8-12 & \\
\hline 8 & $13-20$ & E Aeolian \\
\hline 13 & $21-33$ & $\begin{array}{l}\text { E Aeolian (= E Minor) } \\
\text { E Dorian }\end{array}$ \\
\hline 21 & $34-54$ & $\begin{array}{l}\text { E Dorian } \\
\text { E Mixolydian } \\
\text { E Ionian (= E Major) }\end{array}$ \\
\hline 34 & $55-88$ & $\begin{array}{l}\text { E Ionian (= E Major) } \\
\text { E Lydian } \\
\text { E\# Locrian } \\
\text { E\# (=F) Phrygian }\end{array}$ \\
\hline (1) & 89 & E\# (= F) Phrygian \\
\hline 55 & $90-144$ & $\begin{array}{l}\text { E\# (=F) Phrygian } \\
\text { F Aeolian (= F Minor) } \\
\text { F Dorian } \\
\text { F Mixolydian } \\
\text { F Ionian (= F Major) }\end{array}$ \\
\hline
\end{tabular}

As the numbers of the Fibonacci sequence increase, so the main theme undergoes increasingly elaborate variation and transformation; all subsequent transformations draw on the previous ones, so the entire process appears gradual and 'organic', in accordance with the composer's idea of imitating growth in nature. The most drastic alterations occur in the final segment (No. 55 in the Fibonacci sequence), where the piano textures imitate the ringing of church bells, and the harmonic course moves to the modes in F, with flats (Examples 1a and 1b). At the same time, the St. Lazarus theme in the toy piano hardly changes at all, except for the tonal transformations, if at all possible on the actual instrument used for the performance. 


\section{St Lazarus Valse}

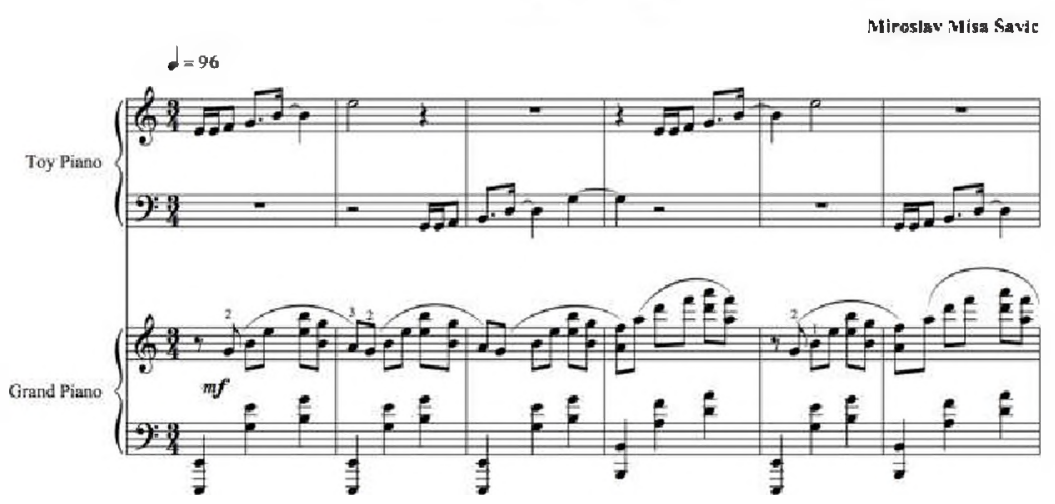

Example 1a: The main theme at the beginning (Fibonacci Nos. 1, 1, 2, 3, 5 / bars 1-12)
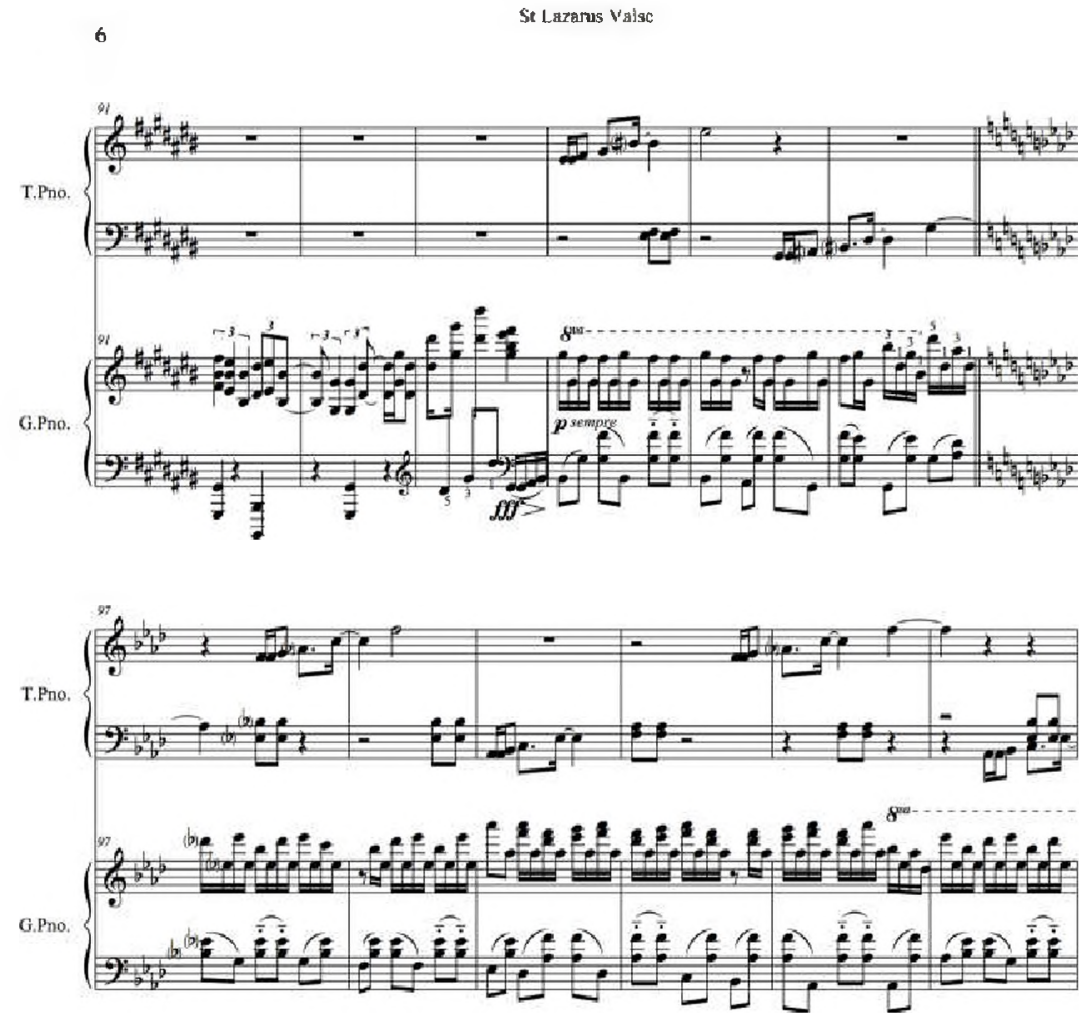

Example 1b: The main theme in the final part of the waltz

(Fibonacci No. 55 / bars 91-102) 


\section{'Parents' and 'Children'}

There are currently four versions of Miroslav Savić's St. Lazarus Waltz, as seen in Table 4:

Table 4: Different versions of St. Lazarus Waltz

\begin{tabular}{|c|c|c|c|}
\hline TITLE & INSTRUMENTS & PREMIERE & PERFORMERS \\
\hline St. Lazarus Waltz & $\begin{array}{l}1 \text { grand piano, } \\
2 \text { toy pianos }\end{array}$ & $\begin{array}{l}\text { Concert 'Waltzes from the } \\
\text { 20th and } 21 \text { st centuries' } \\
\text { 37th BEMUS Festival } \\
\text { Belgrade Philharmonia } \\
\text { Great Hall } \\
\text { Belgrade, } 13 \text { October } 2005\end{array}$ & $\begin{array}{l}\text { Nada Kolundžija } \\
\text { (piano) } \\
\text { LP Duo (toy pia- } \\
\text { nos) }\end{array}$ \\
\hline $\begin{array}{l}\text { The Well-Tem- } \\
\text { pered St. Lazarus } \\
\text { Waltz }\end{array}$ & 2 grand pianos & $\begin{array}{l}\text { Concert 'A Winter Day', } \\
\text { 20th anniversary of Piano } \\
\text { Workshop by Prof. Mi- } \\
\text { lanka Mišević } \\
\text { Kolarac Great Hall, Bel- } \\
\text { grade, } \\
9 \text { December } 2012\end{array}$ & $\begin{array}{l}\text { Ivana Medić } \\
\text { (piano) } \\
\text { Jelena Janković } \\
\text { (piano) }\end{array}$ \\
\hline $\begin{array}{l}\text { A Waltz, All } \\
\text { Dressed Up for the } \\
\text { St. Lazarus Day }\end{array}$ & $\begin{array}{l}1 \text { toy piano and } \\
2 \text { parent-pianos } \\
\text { (i.e.grand pianos) }\end{array}$ & $\begin{array}{l}\text { LP Duo Debut at Carnegie } \\
\text { Hall } \\
\text { Weill Recital Hall } \\
\text { New York, } 17 \text { October } \\
2014\end{array}$ & $\begin{array}{l}\text { LP Duo: } \\
\text { Sonja Lončar } \\
\text { (piano) } \\
\text { Andrija Pavlović } \\
\text { (piano) } \\
\text { Margaret Leng } \\
\text { Tan (toy piano) }\end{array}$ \\
\hline $\begin{array}{l}\text { St. Lazarus \& } \\
\text { Son }\end{array}$ & $\begin{array}{l}1 \text { grand piano, } \\
1 \text { toy piano }\end{array}$ & $\begin{array}{l}\text { 'Ringišpil' [Merry-Go- } \\
\text { Round], Concert of short } \\
\text { piano pieces by Serbian } \\
\text { composers } \\
\text { Students' Cultural Centre } \\
\text { Great Hall } \\
\text { Belgrade, } 31 \text { March } 2016\end{array}$ & $\begin{array}{l}\text { Katarina Rado- } \\
\text { vanović-Jeremić } \\
\text { (piano) } \\
\text { Nada Kolundžija } \\
\text { (toy piano) }\end{array}$ \\
\hline
\end{tabular}


While the complete set of versions follows the narrative of children gradually maturing and eventually leaving their parents' home, the four versions were not written in that exact chronological order; instead, they were the results of the performers' requests. The first version was commissioned by Nada Kolundžija and completed in 2005. Initially it was supposed to be a piece for a partly prepared piano solo; but due to the difficulties that the pianist could encounter while performing, just a few weeks before the concert, Savić and Kolundžija agreed to expand the piece by adding parts for two toy pianos, to be played by the LP Duo (Sonja Lončar and Andrija Pavlović). Thus, the very first version established the 'family ties' between the maverick pianist Nada Kolundžija and her equally adventurous 'musical offspring', the LP Duo.

Since the instruments that the LP Duo had at their disposal for the premiere were really just toys - purely diatonic, without black keys, and with very limited expressive potential - the parts played by these 'children-pianos' had to be very simple. Hence, they consist of a single ascending musical motif that is repeated over and over again, with minor modifications. These small alterations make room for the addition of accidentals, but only if the mechanism of the toy piano permits (which was not the case at the premiere); thus, in this version, only the grand piano is tasked with completing the circle of fifths, while the toy pianos mostly remain tonally placid, thus creating a quirkily dissonant musical current, before ultimately returning to the initial tonal unity. This version bears the title St. Lazarus Waltz: aside from the ubiquitous 'Lazarus' theme in the toy piano parts, the atmosphere of the lively family holiday is musically conveyed by the mechanicistic character of the music, which evokes a merry-go-round, and also by a simulation of the ringing of church bells in the final segment of the composition.

The next version was prepared at the request of the veteran pianist and piano teacher Milanka Mišević, for the $20^{\text {th }}$ anniversary of her ensemble Piano Workshop in December 2012; it was premiered by the author of this text and her twin sister, Jelena Janković (Beguš). This version features two grand pianos, but its musical content is identical to the first version. Since the toy-piano parts are now performed on the second grand piano, it is possible to execute all prescribed modulations, although that part remains quite simple and static, in comparison to the part of the first piano. The composer has said that the version for two 'adult' pianos is, deliberately, somewhat empty and monotonous, because it depicts the situation when the children have grown up and left their parents. On the one hand, the lone parents can now retreat into a quiet life, which is depicted by the lack of dissonant, 'falsch' notes that the mistuned little piano was responsible for; on the other hand, the 'parents-only' version lacks precisely the 
qualities of playfulness and irreverent humour, so typical of the earlier version. The new, slightly modified title also reflects this change: the piece is now called The Well-Tempered St. Lazarus Waltz. Due to the unified sound colour, the emphasis is now indeed placed on the process of modulations through the circle of fifths, which is now a lot more audible and untainted by dissonances, unlike the original version; but the title also symbolises the well-tempered elderly couple, who reminisce about the holidays they celebrated when their offspring were young.

The 2014 version was prepared for LP Duo's concert debut at Carnegie Hall, New York. Among the pieces selected for the most important concert in their career so far, one finds Savić's waltz, but in a wholly new version, called $A$ Waltz, All Dressed Up for St. Lazarus Day - and the part for the little piano is indeed all dressed up! The composer Miloš Raičković, a mutual friend of Savić and LP Duo, suggested that the toy piano part should be played by the New York-based Chinese-American musician Margaret Leng Tan (b. 1945), who is a professional toy pianist and an avid collector of toy pianos. Upon visiting Leng Tan's New York home with Raičković, Savić discovered that she owned more than 100 different toy pianos, with very diverse and versatile technical and acoustic abilities. ${ }^{5}$ In this version, Savić transposed the piece to $\mathrm{F}$ minor and transferred some of the material from grand pianos to the toy piano, because the technically more complex toy instruments owned by Margaret Leng Tan allowed for a more elaborate part. Rather than simply repeating the same tune all over again, the little piano now has some prominent solo appearances (Example 2), plus an all-round technically more demanding part, almost on equal terms with the grand pianos. The composer said that in this version, the child is no longer a toddler, but a slightly older and more mature youngster, who has nevertheless preserved its juvenile energy and playfulness. ${ }^{6}$ In spite of the transposition, the overall form and the sequence of tonal/modal changes remained unaltered.

The latest version (so far) was prepared in 2016; it is called 'St. Lazarus \& Son' and it features one grand piano and one toy piano. It was premiered by Katarina Radovanović-Jeremić and Nada Kolundžija; while the latter had previously been responsible for the 'adult' piano parts, in this version she plays the role of the 'son'. Musically, this version is an amalgam of all the previous versions.

5 From my conversation with Miroslav Savić, 28 February 2017, Institute of Musicology SASA, Belgrade.

6 Ibid. 


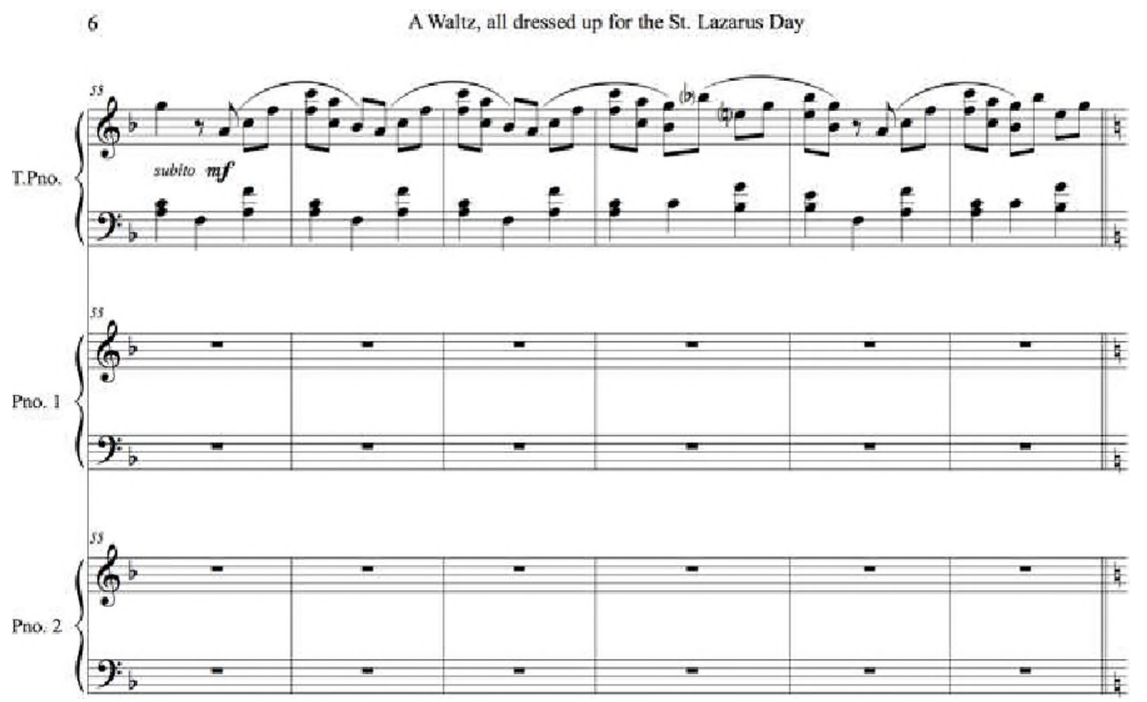

Example 2: The toy-piano 'solo' in the 2014 version (Fibonacci No. 34 / bars 55-60)

\section{History Repeated... and Repeated}

There are five discernible layers of music embedded in the St. Lazarus Waltz, which situate it firmly into the postmodern way of musical thinking. Such overt referentiality is quite atypical for Savic's oeuvre in general, and it signals that the composer has reached the stage in his career where he is comfortable with the fact that his strictly minimalist and experimental days are over, and thus feels inspired to reacknowledge various artefacts from both European and specifically Serbian music history. The layers of references (some of which I have already mentioned) include:

1) J. S. Bach and other composers who wrote 'well-tempered' piano music;

2) the Serbian Orthodox tradition,

3) the Serbian tradition of romantic salon piano pieces;

4) the music of Vasilije Mokranjac;

5) repetitive/processual minimalism.

Since the well-temperedness of the St. Lazarus Waltz has already been established above, now is the moment to focus on the other layers of musical references, starting with the oldest one. Namely, church music is by far the oldest genre in Serbian music, dating as far back as the Christenisation of the Balkan 
tribes. ${ }^{7}$ Born in 1954, Savić belongs to the generation that was brough up after World War II, in the Socialist Federal Republic of Yugoslavia, governed by Josip Broz Tito and the Communist Party; while not officially banned, religion was very much out of favour. The composer recalls that, growing up next to the Church of St. Mark in central Belgrade, he never attended Lazarus Saturday as a child; he also recalls that his grandfather celebrated the family saint (the so-called slava) clandestinely, in a remote village, and that Savić was warned by his family not to tell his schoolmates about these festivities. ${ }^{8}$ Hence, he only discovered Lazarus Saturday in the 1980s, after Tito's death, when communist constraints were already in the process of disintegration; and he was happy to take his own children to celebrate this holiday, not because he had suddenly become religious, but because his children were excited about it.9

It should be mentioned here that already in the 1950s a new trend had emerged within the nascent Serbian musical modernism: an idiosyncratic intertwining of the various neo-styles with elements of the suppressed Orthodox tradition. This trend was distinguished by a nostalgic/poeticised relation towards the distant past (in particular, the idealised Middle Ages), and the aim of reviving the 'archaic' by using contemporary artistic means. Ljubica Marić (1910-2003), although herself a former Communist and presumed agnostic, based a number of her most important orchestral, vocal and concertante works on quotations from Stevan Mokranjac's edition of Octoechos (published in 1908) - a collection of traditional church songs in eight modes for Sunday services; other composers soon followed suit. However, while this Octoehos-inspired style was very prominent in the genres such as choral, orchestral and stage music, it left comparably little trace in chamber music and music for solo instruments - mostly due to the basic incompatibility of the Orthodox chants with the typical demands of instrumental music genres.

Then, a new stage in the development of Serbian church and church-inspired music began with the onset of nationalism and the dissolution of Yugoslavia in the late 1980s and early 1990s. Almost overnight, a glorification of the long-shunned religious past became fashionable, and a host of Serbian composers started writing liturgical music, or music inspired by church music or

\footnotetext{
${ }^{7}$ Ivana Perković-Radak, "Crkvena muzika" [Church Music] in: Mirjana Veselinović-Hofman et al., Istorija srpske muzike - Srpska muzika i evropsko muzičko nasleđe, [Serbian Music History - Serbian Music and European Heritage], Belgrade, Zavod za udžbenike i nastavna sredstva, 2007, 299.

8 From my conversation with Miroslav Savić, 28 February 2017, Institute of Musicology SASA, Belgrade.

9 Ibid.
} 
church texts, but not liturgical in the narrow sense of the word - among them Aleksandar Vujić (b. 1945), Ivan Jevtić (b. 1947), Minta Aleksinački (b. 1947), Miodrag Govedarica (b. 1950), Dimitrije Golemović (b. 1954), Jugoslav Bošnjak (b. 1954), Svetislav Božić (b. 1954) and many others. And while some of them used actual quotations of chants, others used a more tangential approach; this development parallelled similar movements in almost all the countries of the former Eastern Bloc. ${ }^{10}$ However, Savic does not show any kinship with these 'neo-Orthodox' composers, but rather with the late oeuvre of Milimir Drašković, a former OPUS 4 member. As stated by Ivana Miladinović-Prica, after reaching the pinnacle of reductionism, starting from the late 1980s, Drašković began composing pieces whose goal was

[an] 'ideological escape from Western rationality' [...] As the result of his need for escapism and his disagreement with the stereotypes in the Balkans and the Byzantine (music) tradition as a non-European religious and cultural Other, Drašković created a series of works, by fusing Serbian Orthodox church chant, e.g. melodies of the Osmoglasnik [Octoechos] notated by Stevan Stojanović Mokranjac (1856-1914) in 1908, with improvisation, jazz and rock music - Prva nedelja [First week] for three saxophones (1992), Osam nedelja [Eight weeks] for jazz ensemble (1995) and Nedelja [Week] for electric guitar (1996). ${ }^{11}$

While their works do share a certain aural affinity, unlike Drašković, Savić does not use any recognisable 'signifiers' of church music, such as ison (drone), quotations of chants, singing in a specific 'chanting' manner and such. ${ }^{12}$ Instead, in St. Lazarus Waltz, Serbian Orthodox tradition is only referenced by the title of the piece, the melody ('St. Lazarus theme') that is constantly repeated (but, as the composer himself has stated, more like a mantra than an actual chant), and the simulation of bells ringing in the final section of the piece. On the other hand, the overall mechanicist character and humorously dissonant harmonic language of St. Lazarus Waltz firmly separate Savić's work from the bulk of 'neo-Orthodox' compositions.

10 Cf. Ivana Medić, "I Believe... In What? Alfred Schnittke's and Arvo Pärt's Polystylistic Credos", Slavonica, 2010, 16/2, 96-111.

11 Ivana Miladinović-Prica, "The background of Milimir Draškovic's communication with the cultural Other", in: Ivana Medić and Katarina Tomašević (Eds.), Beyond the East-West Divide: Balkan Music and its Poles of Attraction, Belgrade, Institute of Musicology SASA and Serbian Academy of Sciences and Arts, 2015, 225.

12 Cf. Mirjana Veselinović-Hofman, "Muzika u drugoj polovini XX veka" [Music in the Second Half of the 20th Century] in: Veselinovic Hofman et al, op. cit., 129; Melita Milin, "Old Serbian Church Music in the Works of Contemporary Composers", Music and Society in Eastern Europe, 2006, 1, 94. 
As for the next reference, the development of Serbian salon piano music coincided with the country's liberation from Ottoman rule in the 19th century, and the ensuing urbanisation, industrialisation and the emergence of the bourgeois class, complemented by a strong movement towards national unification. The very first known Serbian piano piece was - a waltz: it was written in 1841 by a composer of Greek descent, Aleksandar Morfidis-Nisis (1803-1877), with a poetic title Pozdrav srpskim devama [A Salute to Serbian Maidens]. ${ }^{13}$ This inaugural waltz was followed by a host of similar salon pieces written by the likes of Kornelije Stanković (1831-1865), Robert Tolinger (1859-1911), Isidor Bajić (1878-1915) and many others. And while Savić's entire oeuvre is decidedly anti-Romantic in every possible facet, he was aware that, by accepting to write a waltz for the piano, he could not escape its Romantic patina. ${ }^{14}$

Moreover, Savić has admitted another source of subconscious, but undeniable inspiration, that ties him both to the Orthodox heritage and to (neo-)Romanticism - the late piano opus of his composition teacher Vasilije Mokranjac. Not only was Vasilije Mokranjac one of the few composers of the generation born in the 1920s and 1930s who devoted a great deal of his creative energy to enriching the relatively modest Serbian repertoire for the piano, but in his work from the 1970s, Orthodox chants for the first time found their way into Serbian music for the piano. His works for this instrument are stylistically heterogeneous, bearing traces of romanticism, impressionism, expressionism and popular music styles such as jazz, and often imbued with folklore inflections - albeit only at the level of simulation, not actual quotation. After a fifteen-year hiatus from piano music (1958-1973), Mokranjac completed two works for the piano in 1973: Intime [Intimacies] and Odjeci [The Echoes]. The latter instantly became one of the landmarks of Serbian piano music. The subject matter of this composition could be defined as a return to spirituality, a quest for peace and balance, which have been lost in modern life. While the work is written around the quotation of a Byzantine chant, its philosophical outreach is not solely Orthodox, but it can be said to branch into other religious and philosophical teachings, from neo-Platonism to Buddhism. ${ }^{15}$ As to Savić's sentiment towards his professor, he has admitted that, as a young composer, he did not feel any kinship with Mokranjac's oeuvre, especially with his works from the 1950 s that carried a strong folklore flavour.

13 Dragana Jeremić Molnar, "Klavirska muzika romantičarskog doba" [Piano Music of the Romantic Era], in: Veselinović-Hofman et al., op. cit, 405.

14 From my conversation with Miroslav Savić, 28 February 2017, Institute of Musicology SASA, Belgrade.

15 For a detailed analysis of The Echoes, see: Ivana Medić, Klavirska muzika Vasilija Mokranjca [Piano Music of Vasilije Mokranjac], Belgrade, Students Cultural Centre, 2004, 80-86. 
However, in recent years, Savić has rediscovered Mokranjac's output, with a renewed appreciation for his neo-Romantic and neo-Impressionist works from the 1970s and 1980s. And, just like Mokranjac does not attempt to reconstruct the Orthodox liturgy in The Echoes, but only to reflect on some of its constitutive elements - the bells ringing, the priest chanting, the choir singing, the prayer neither does Savić wish to imitate the St. Lazarus rite (which is impossible in his chosen media, the piano); instead, he only evokes the bare minimum of its recognisable elements and creates a new work of art.

The final layer of musical referentiality is Savić's own minimalist, processual and subversively experimentalist musical past, which is reflected in the fact that the entire work is based on the bare minimum of thematic material, which is relentlessly repeated throughout the piece. Four decades ago Savić and his cohort introduced repetitive/processual minimalism into Serbian art music. But while Savić never completely abandoned such procedures, the principles of processuality and repetitiveness have gradually evolved; in this particular piece, Savić assigns to them the task of depicting the growth of a plant from a miniature seed. The process itself is controlled by the Fibonacci sequence and the circle of fifths; as we have seen, Savić's idea was that he should 'exclude' the composer i.e. himself, as much as possible, because, just as the growth of a plant is genetically programmed, so should the Fibonacci-based form be allowed to 'grow' according to the 'laws of nature'. Whilst referencing his minimalist past, Savić actually deconstructs the typical minimalist procedures and assigns to them a 'programmatic' role. In Savić's opinion, the old processual music in which a single process is showcased, to be listened to from the beginning to the end, is no longer a viable compositional 'ideology'. Savić is now happy to interrupt certain processes, to shorten them, to start them all over again, to let them develop in different directions and, last but not least, to follow his musical intuition, whilst staying true to his processual roots.

Miroslav Savić's St. Lazarus Waltz, in all its different manifestations, shows that the composer has reached a professional and personal maturity. The different referential layers act simultaneously to create a piece that can be read in multiple ways, such as: the composer's nostalgic reflection on the merry Lazarus Saturday; a nod to Savić's maverick minimalist and experimental youthful works; and a celebration of the instrument of the piano in all of its varieties. While Savić does not cite any church melodies, or any other elements of the Orthodox rites, he does share with listeners his reflections on the merry spring holiday and shows us how they resonate in his (sub)conscious. In this way, the St. Lazarus Waltz blurs the difference between the old and the new, and depicts the quest by a (post)modern man who finds solace in Nature and the spiritual. However, the listeners are deliberately left uncertain about whether Savić wants to reaffirm 
and delve into the Serbian Orthodox tradition (which is not entirely implausible, given that at least two members of his former minimalist clique, Milimir Drašković and Miloš Petrović, made similar excursions), or he actually parodies the countless 'new-Orthodox' works, since the only actual citation - the main theme in the grand piano - is chosen completely randomly, and the boundaries between the composer's 'true' voice and a mimicry of something else are constantly blurred. In any case, Savić has created an intriguing postmodern musical riddle that is simultaneously original and recapitulatory, introspective and engaging, (auto-)reflective and challenging, profound and cheeky.

\section{References}

Jeremić-Molnar, Dragana: "Klavirska muzika romantičarskog doba" [Piano Music of the Romantic Era] in: Mirjana Veselinović-Hofman et al., Istorija srpske muzike Srpska muzika i evropsko muzičko naslede, [Serbian Music History - Serbian Music and European Heritage], Beograd: Zavod za udžbenike i nastavna sredstva, 2007, 405-422.

Masnikosa, Marija: Muzički minimalizam: američka paradigma i differentia specifica $u$ ostvarenjima grupe beogradskih kompozitora [Musical Minimalism: American Paradigm and Differentia Specifica in the Works by a Group of Belgrade Composers], Beograd: Clio, 1998.

---: “The Reception of Minimalist Composition Techniques in Serbian Music of the Late 20th Century", New Sound 40, II, 2012, 181-190.

Medić, Ivana: Klavirska muzika Vasilija Mokranjca [Piano Music of Vasilije Mokranjac], Beograd: Studentski Kulturni Centar, 2004.

---: "I Believe... In What? Alfred Schnittke's and Arvo Pärt's Polystylistic Credos", Slavonica, 16/2, 2010, 96-111.

Miladinović-Prica, Ivana: "The Background of Milimir Drašković's Communication with the Cultural Other", in: Ivana Medić and Katarina Tomašević (Eds.), Beyond the East-West Divide: Balkan Music and its Poles of Attraction, Belgrade, Institute of Musicology SASA and Serbian Academy of Sciences and Arts, 2015, 222-233.

Milin, Melita: "Old Serbian Church Music in the Works of Contemporary Composers", Music and Society in Eastern Europe, 1, 2006, 93-99.

Perković-Radak, Ivana: “Crkvena muzika" [Church Music] in: Mirjana Veselinović-Hofman et al., Istorija srpske muzike - Srpska muzika i evropsko muzičko nasleđe, [Serbian Music History - Serbian Music and European Heritage], Beograd: Zavod za udžbenike i nastavna sredstva, 2007, 297-330.

Savić, Miroslav Miša: Animirani brojevi - Animated Numbers, Belgrade, Vertical Jazz, 2016.

Veselinović-Hofman, Mirjana: "Muzika u drugoj polovini XX veka" [Music in the Second Half of the 20th Century] in: Mirjana Veselinović-Hofman et al., Istorija srpske muzike - Srpska muzika i evropsko muzičko nasleđe, [Serbian Music History Serbian Music and European Heritage], Beograd: Zavod za udžbenike i nastavna sredstva, 2007, 107-135. 